DedikasiMU (Journal of Community Service)

Volume 3, Nomor 1, Maret 2021

\title{
MENINGKATKAN MINAT BELAJAR ANAK DENGAN \\ PEMBELAJARAN DI LUAR KELAS MELALUI PENERAPAN "SENSORY PLAY" DI KB PUSPA GIRI INDRO
}

\author{
${ }^{1}$ Ika Ainun Munzilin, ${ }^{2}$ Riska Widiyanita Batubara, ${ }^{3}$ Nur Fauziyah, ${ }^{4}$ Sukaris, ${ }^{5}$ Andi Rahmad Rahim \\ ${ }^{1}$ Mahasiswa Program Studi PIAUD, Universitas Muhammadiyah Gresik \\ ${ }^{2}$ Dosen Pendidikan Bahasa Inggris Universitas Muhammadiyah Gresik \\ ${ }^{3}$ Dosen Program Studi Pendidikan Matematika, Universitas Muhammadiyah Gresik \\ ${ }^{4}$ Dosen Program Studi Manajemen, Universitas Muhammadiyah Gresik \\ ${ }^{5}$ Dosen Program Studi Budidaya Perikanan, Universitas Muhammadiyah Gresik \\ Email : ainunika01@gmail.com
}

\begin{abstract}
ABSTRAK
Anak usia dini merupakan kelompok usia yang berada dalam proses perkembangan unik kerena proses perkembangannya. Dimana perkembangan otak anak sangat pesat atau bisa disebut sebagai masa Golden Age Anak usia dini juga merupakan masa terpenting pada untuk mengasah indra dan melatih otot-otot mereka. Berdasarkan hasil observasi dapat disimpulkan bahwa kegiatan belajar di KB Puspa Giri Indro masih menggunakan sistem belajar dengan menggunakan LKS yang menjadi acuan utama guru dalam mengajar sehingga membuat anak menjadi cepat bosan dan jenuh. Sensory Play adalah permainan menyenangkan digunakan dalam pembelajaran yang dapat melatih anak dengan menggunakan satu indra atau lebih (penglihatan, pendengaran, penciuman, pengecapan dan peraba). Permainan ini berguna untuk mendorong anak untuk belajar observasi, menstimulasi indra, dan membangun hubungan syaraf di otak. Saat stimulus masuk ke dalam otak anak, sistem syaraf kemudian akan memprosesnya dengan menghasilkan sebuah sensasi yang mendorong indra anak bergerak. Pembelajaran di luar kelas merupakan suatu kegiatan di luar kelas yang menjadikan pembelajaran di luar kelas menarik dan menyenangkan, serta lebih menyatu dengan alam, yang berarti anak akan memperoleh kesempatan untuk mengobservasi, memperoleh informasi atau mengkaji segala sesuatu secara langsung. Selain itu, belajar secara nyata diluar kelas, dapat lebih menstimulasi fisik dan emosi. Meningkatnya rasa percaya diri, dan juga juga dapat membawa mereka pada perasaan mencintai tempat yang berada dalam lingkungan anak.
\end{abstract}

Kata Kunci: Pendidikan Anak Usia Dini, Sensory Play, Pembelajaran diluar Kelas. 


\section{DedikasiMU (Journal of Community Service)}

Volume 3, Nomor 1, Maret 2021

\section{PENDAHULUAN}

\section{A. Latar Belakang}

Anak usia dini merupakan kelompok usia yang berada dalam proses perkembangan unik kerena proses perkembangannya. (Maria, 2012) pada usia ini perkembangan otak anak berkembangan dengan sangat pesat. Stimulasi merupakan hal yang penting dalam tumbuh kembang anak. Hal ini berarti bahwa anak mendapat stimulasi yang terarah dan teratur akan lebih cepat berkembang. Menstimulasi anak usia prasekolah dapat dilakukan dengan cara bermain.

Dunia anak adalah dunia bermain, yaitu dunia yang penuh dengan spontanitas dan menyenangkan. Sesuatu yang dilakukan anak penuh dengan semangat apabila terkait dengan suasana yang menyenangkan. Anak akan membenci dan menjauhi suasana yang tidak menyenangkan. Bermainan adalah suatu bentuk penyesuaian diri manusia yang sangat berguna menolong anak menguasai kecemasan dan konflik. Piaget melihat permainan sebagai suatu metode yang meningkatkan perkembangan kognitif anak-anak Bermain secara tidak langsung akan membuat anak mengembangkan kemampuan fisik - motorik, sosial - emosional, dan kognisinya.

Anak usia dini juga merupakan masa terpenting untuk mengasah indra dan melatih otototot anak. Hal tersebut dapat diasah dengan penggunaan permainan sederhana yang menggunakan metode yang sedang berkembang yaitu metode belajar Sensory Play. Sensory Play merupakan kegiatan yang dilakukan diluar kelas untuk mendorong anak - anak menggunakan salah satu indra atau lebih, seperti permainan tebak suara, permainan melompat, mengikuti garis, permaianan dengan sentuhan dan lain sebagainya. Pembelajaran diluar kelas dengan menggunakan Sensory Play tidak hanya menekankan pemahaman terhadap pelajaran, menstimulasi alat indera tetapi juga dapat memperhatikan kemampuan mereka dalam mempraktikannya secara langsung.

Hingga saat ini, tidak banyak sekolah yang menerapkan sistem belajar di luar kelas. Umumnya, mereka masih menggunakan metode klasik, yaitu mengajar didalam kelas. Hal ini kemungkinan disebabkan karena kebanyakan guru tidak memahami apa itu pembelajaran diluar kelas serta kurang mengerti pentingnya mengajar di luar kelas, sehingga metode mengajar klasik selalu menjadi acuan utamanya dalam mengajar. 


\section{DedikasiMU (Journal of Community Service)}

\section{Volume 3, Nomor 1, Maret 2021}

Maka dari itu, dalam penelitian ini, peneliti ingin meneliti tentang peningkatan pembelajaran diluar kelas untuk peserta didik melaui penerapan Sensory Play di KB Puspa Giri Indro untuk menghasilkan sebuah sensasi yang mendorong indra anak bergerak (respon stimulus). Semakin banyak stimulus yang diberikan, semakin banyak anak akan mendapatkan pengalaman yang menyenangkan. Tentunya, setiap stimulus akan menghasilkan respon yang berbeda.

\section{B. Rumusan Masalah}

Berdasarkan latar belakang diatas, rumusan masalah dalam peneilitian ini adalah bagaimana meningkatkan minat belajar anak dengan pembelajaran diluar kelas melalui penerapan Sensory Play di KB Puspa Giri Indro.

\section{Tujuan Penelitian}

Tujuan dari penelitian ini untuk menjawab rumusan masalah yaitu untuk meningkatkan minat belajar anak dengan pembelajaran di luar kelas melalui penerapan Sensory Play untuk peserta didik di KB Puspa Giri Indro.

Adapun tujuan lain yaitu, mendorong anak menggunakan satu indra atau lebih untuk belajar dan memahami sesuatu menggunakan koordinasi mata, tangan dan kaki dan membantu perkembangan bahasa, motorik kasar, kognitif dan sosial emosional.

\section{Manfaat Kegiatan}

Terdapat beberapa manfaat yang dapat diambil dari penelitian ini, yakni:

1) Sistem pembelajaran akan berjalan lebih menyenangkan dari pada hanya monoton di dalam kelas.

2) Sistem pembelajaran menjadi lebih nyata karena berbagai objek pembelajarannya dapat dilihat bahkan dirasakan langsung.

3) Sistem pembelajaran menjadi jelas dan menarik

4) Proses pembelajaran menjadi lebih interaktif karena dengan media akan terjadinya komukasi dua arah secara aktif, sedangkan tanpa media guru cenderung bicara satu arah,

5) Meningkatkan kualitas hasil belajar anak,

6) Melatih perkembangan otak anak

7) Membantu perkembangan bahasa, motorik halus kasar, kognitif, dan sosial emosional. 


\section{DedikasiMU (Journal of Community Service)}

Volume 3, Nomor 1, Maret 2021

\section{METODE PENELITIAN}

\section{A. Perancangan Kegiatan}

Adapun proses perancangan kegiatan dalam pembuatan Sensory Play yaitu dengan observasi terlebih dahulu dengan mengikuti pendampingan kegiatan belajar mengajar didalam kelas.

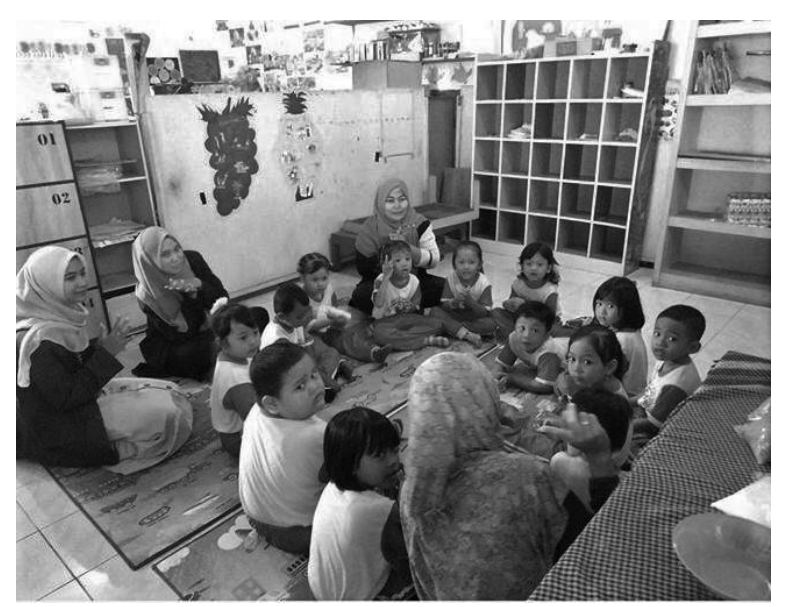

Gambar 1. Observasi kegiatan belajar mengajar

Berdasarkan hasil observasi dapat disimpulkan bahwa kegiatan belajar masih menggunakan sistem belajar menggunakan LKS dan menjadi acuan utama guru dalam mengajar sehingga membuat anak menjadi cepat bosan dan jenuh.

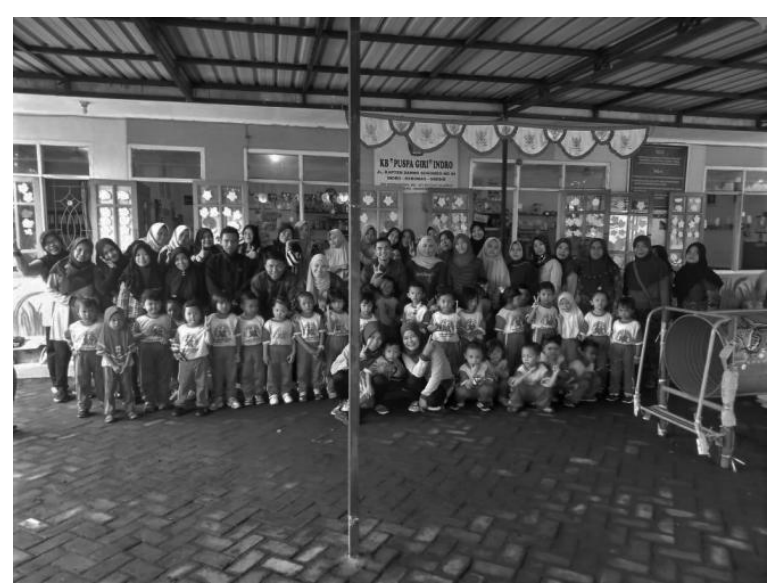

Gambar 2. Observasi di luar kelas 


\section{DedikasiMU (Journal of Community Service)}

Volume 3, Nomor 1, Maret 2021

Selain itu, penulis juga mengindentifikasi masalah dengan melakukan wawancara kepada guru kelas.

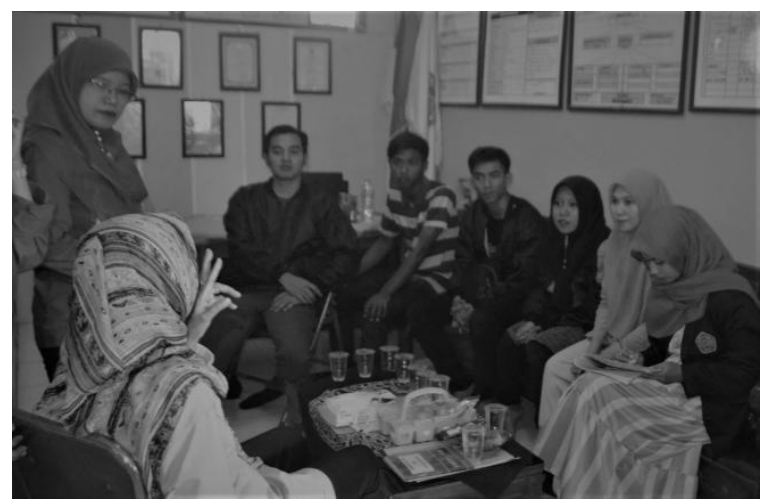

Gambar 3. Wawancara dengan guru kelas

Berdasarkan hasil wawancara dapat disimpulkan bahwa kurangnya fasilitas/media untuk kegiatan belajar yang menyenangkan. Selanjutnya, perencanaan penulis untuk membuat media Sensory Play diluar kelas dengan cara mengecat.

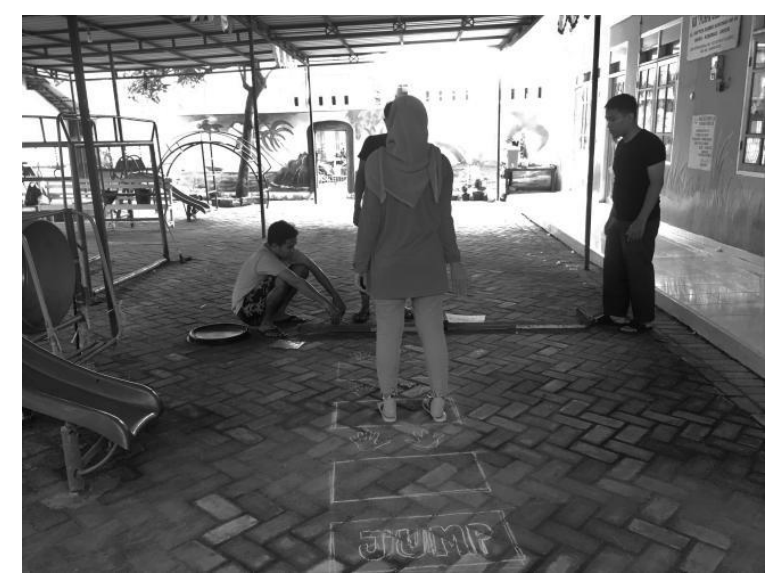

Gambar 4. Perencanaan pembuatan "Sensory Play"

Karena melalui pembelajaran di luar kelas menggunakan penerapanan Sensory Play peserta didik di KB Puspa Giri Indro diharap dapat meningkatkan minat belajar dan perkembangan anak.

\section{B. Subjek}

Subjek dalam penelitian ini adalah anak - anak usia dini yang bergabung dalam Kelompok Bermain (PAUD) di KB Puspa Giri Indro. 


\section{DedikasiMU (Journal of Community Service)}

Volume 3, Nomor 1, Maret 2021

C. Alat dan Bahan
a. Cat Kayu Warna
b. Tinner
c. Kuas
d. Kapur
e. Penggaris Kayu

\section{Waktu dan Tempat}

Adapun kegiatan dilakukan pada:

Hari : Sabtu dan Minggu

Tanggal : 15-16 Februari 2020

Tempat : Halaman Sekolah KB Puspa Giri Indro

\section{E. Teknik Pengumpulan Data}

Pengumpulan data dilakukan dengan melakukan observasi kelas untuk mengatahui secara langsung metode belajar mengajar dalam kelas, wawancara terhadap guru untuk mengetahui tingat belajar didalam kelas menggunakan LKS dan teknik dokumentasi.

\section{F. Definisi Operasional Variabel}

a. Pembelajaran di Luar Kelas

Pembelajaran di luar kelas merupakan suatu kegiatan di luar kelas yang menjadikan pembelajaran di luar kelas menarik dan menyenangkan, serta lebih menyatu dengan alam, berarti anak memperoleh kesempatan untuk mengobservasi, memperoleh informasi atau mengkaji segala sesuatu secara langsung (Jamaris,2006)

Belajar secara nyata diluar kelas, dapat lebih menstimulasi fisik dan emosi. Meningkatnya rasa percaya diri, dan rasa memiliki yang dimiliki seorang anak akan memperbaiki perilaku mereka. Dengan mendengar, membau, mencicipi, dan merasakan keaneragaman dan keindahan alam, tidak hanya meningkatkan kemampuan panca indera dan pengetahuan yang dimiliki anak, tetapi juga dapat membawa mereka pada perasaan mencintai tempat yang berada dalam lingkungan anak.

Pepen Supandi (2007) mengemukakan ada dua alasan kenapa bermain di luar kelas dipakai untuk belajar pada PAUD. Pertama banyak kemampuan anak yang harus dikembangkan. Kedua orang tua yang sibuk selalu memberikan permainan komputer, laptop, atau nonton televisi sehingga menyebabkan anak jauh dari kegiatan bermain. 


\section{DedikasiMU (Journal of Community Service)}

\section{Volume 3, Nomor 1, Maret 2021}

Bermain diluar kelas juga menjadi permainan yang diberikan pada anak usia dini dengan bermain dan belajar mengenalkan alam dan menggunakan bermacam area dialam yang natural sehingga anak dapat mengobservasi benda benda alam yang ada disekitarnya serta akan mendapatkan pengalaman yang unik

\section{b. Sensory Play}

Sensory play berasal dari kata sense dan play. Kata sense atau yg lebih sering disebut dengan indra, adalah 5 indra manusia yg terdiri dari: penglihatan (mata), penciuman (hidung), pendengaran (telinga), perabaan (kulit) dan perasa/pengecapan (lidah), serta ditambah dengan pergerakan (proprioseptif: otot dan sendi) serta keseimbangan (vestibular: telinga bagian dalam). Kata play memiliki arti bermain.

Sensory Play adalah permainan yang melatih dan menggunakan satu indra atau lebih (penglihatan, pendengaran, penciuman, pengecapan dan peraba). Permainan ini berguna untuk mendorong anak untuk belajar observasi, menstimulasi indra, dan membangun hubungan syaraf di otak. Perkembangan anak dalam hal belajar juga tidak hanya berasal dari faktor genetik saja melainkan juga dari stimulus yang diberikan oleh lingkungan sekitarnya. Saat stimulus masuk ke dalam otak anak, sistem syaraf kemudian akan memprosesnya dengan menghasilkan sebuah sensasi yang mendorong indera anak bergerak (respon stimulus). Semakin banyak stimulus yang diberikan, semakin banyak anak akan mendapatkan pengalaman yang menyenangkan.

Sensory play mengaktivasi potensi diri dan kreativitas anak sesuai dengan perkembangannya. Kegiatan ini pun dapat mencakup berbagai area pembelajaran. Seperti matematika, bahasa, sains, keterampilan hidup, juga pengembangan motorik halus dan kasar. Anak-anak juga merasa bahagia karena seluruh indra mereka dirangsang dalam atmosfer yang positif.

\section{HASIL DAN PEMBAHASAN}

\section{A. Hasil}

Berdasarkan pelaksanaan pembelajaran dengan penerapan Sensory Play peserta didik lebih sering bermain sambil belajar diluar kelas sehingga mendapatkan pengalaman yang menyenangkan dan mempraktikkan secara langsung, peserta didik mampu mengembangkan kreativitas dan inisiatif mereka secara personal, dapat meningkatkan ketertarikan peserta didik pada kegiatan Sensory Play yang ada di luar kelas, selain itu, 


\section{DedikasiMU (Journal of Community Service)}

Volume 3, Nomor 1, Maret 2021

perkembangan bahasa, kognitif, motorik kasar, sosial emosional, serta kemampuan koordinasi mata dan tangan terasah.

Pelaksanaan pembelajaran dengan penerapan Sensory Play juga berpengaruh untuk guru yaitu, penyampaian materi pelajaran dapat diseragamkan, proses pembelajaran menjadi lebih jelas dan menarik, dan proses pembelajaran menjadi lebih interaktif. Selain itu, dengan penerapan model pembelajaran ini guru dapat lebih efisien dalam hal waktu dan tenaga, serta meningkatkan kualitas hasil belajar siswa. Dan tentunya halaman sekolah tidak membosankan karena terdapat permainan baru dengan model yang berbeda sehingga menjadikan halaman sekolah indah dan lebih berwarna.

\section{B. Pembahasan}

Dalam artikel penelitan ini, bermain secara tidak langsung akan membuat anak mengembangkan kemampuan fisik - motorik, sosial - emosional, dan kognisinya. Anak usia dini juga merupakan masa terpenting untuk mengasah indra dan melatih otot-otot anak. Hal tersebut dapat diasah dengan permainan sederhana menggunakan metode yang sedang berkembang yaitu metode belajar Sensory Play. Pembelajaran diluar kelas dapat mempengaruhi perkembangan anak dan memberi kesempatan untuk peserta didik dalam merasakan secara langsung pada pembelajaran yang sudah disampaikan.

Sehingga, media Sensory Play yang digunakan dalam pembelajaran kelas dapat dikatakan sebagai pembelajaran yang menyenangkan dan dapat mengasah indera serta melatih otot-otot anak. Perkembangan anak dalam hal belajar,juga tidak hanya berasal dari faktor genetik saja melainkan juga dari stimulus yang diberikan oleh lingkungan sekitarnya. Saat stimulus masuk ke dalam otak anak, sistem syaraf kemudian akan memprosesnya dengan menghasilkan sebuah sensasi yang mendorong indera anak bergerak. 


\section{DedikasiMU (Journal of Community Service)}

Volume 3, Nomor 1, Maret 2021

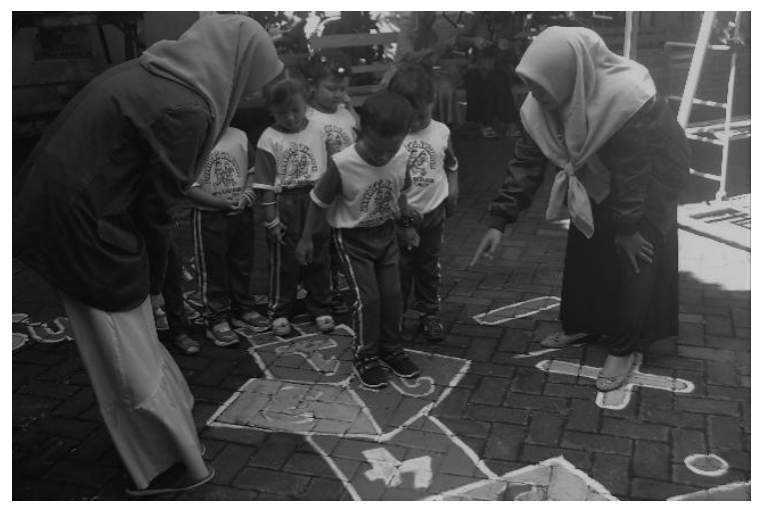

Gambar 5. Penerapan Sensory Play

Dalam berlangsungnya kegiatan pembuatan Sensory Play penulis dengan bantuan teman - teman mahasiswa KKN yang lain menggambar serta mengecat 4 macam permainan Sensosy Play di halaman sekolah KB Puspa Giri Kelurahan Indro dengan saling berkoordinasi hanya saja terdapat beberapa hambatan kecil seperti cuaca hujan yang menyebabkan pembuatan Sensory Play tertunda dan selesai tidak sesuai dengan waktu yang telah ditentukan

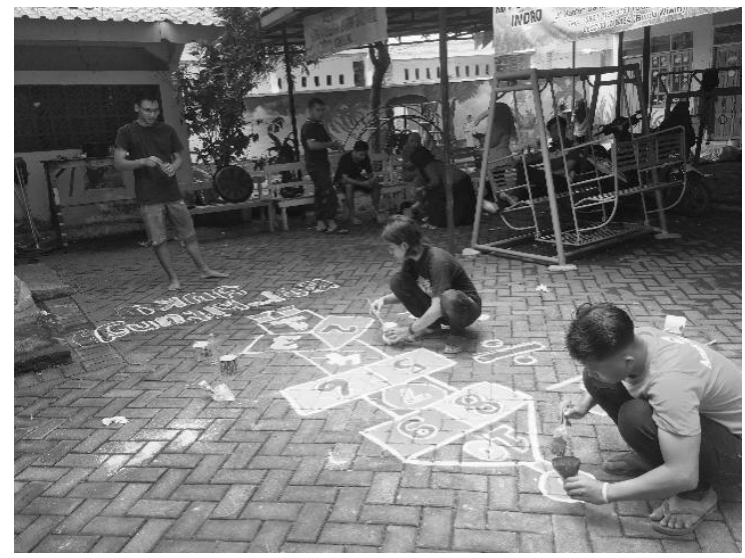

Gambar 6. Proses Pembuatan Sensory Play 


\section{DedikasiMU (Journal of Community Service)}

Volume 3, Nomor 1, Maret 2021

\section{KESIMPULAN DAN SARAN}

\section{A. Kesimpulan}

Berdasarkan hasil kegiatan yang dilakukan, dapat disimpulkan bahwa sistem belajar menggunakan LKS menjadi acuan utama guru dalam mengajar sehingga membuat anak menjadi bosan dan jenuh. Melalui pembelajaran di luar kelas menggunakan penerapanan Sensory Play anak akan mendapatkan pengalaman yang menyenangkan dan dapat mempraktikkan secara langsung.

Perkembangan anak dalam hal belajar juga tidak hanya berasal dari faktor genetik saja melainkan juga dari stimulus yang diberikan oleh lingkungan sekitarnya. Saat stimulus masuk ke dalam otak anak, sistem syaraf kemudian akan memprosesnya dengan menghasilkan sebuah sensasi yang mendorong indera anak bergerak (respon stimulus) selain itu, perkembangan bahasa, kognitif, motorik kasar, sosial emosional, serta kemampuan koordinasi mata dan tangan terasah.

\section{B. Saran}

Proses pembelajaran pada anak usia dini lebih baiknya menggunakan model pembelajaran yang bervariasi, menarik dan menyenangkan untuk pemberian stimulus pendidikan. Hal ini dikarenakan kualitas perkembangan anak dimasa depannya, sangat ditentukan oleh stimulus yang diperolehnya sejak dini. Selain itu, guru diharapkan mampu menciptakan suasana dimana peserta didik tidak merasa terlalu dinilai oleh orang lain, dan dapat memberikan pengertian dalam arti dapat memahami pemikiran, perasaan, dan perilaku peserta didik sama halnya dengan dapat menempatkan diri dalam situasi peserta didik, serta melihat sesuatu dari sudut pandang mereka. Sehingga hal ini akan dapat mengoptimalkan perkembangan anak usia dini. 


\section{DedikasiMU (Journal of Community Service)}

Volume 3, Nomor 1, Maret 2021

\section{DAFTAR PUSTAKA}

Yusiana, Maria, 2012, Peran Orangtua Dalam Kegiatan Bermain Dalam Perkembangan Kognitif Anak Usia Prasekolah, jurnal STIKES Volume 5, No. 2, Desember 2012.

Martini, Jamaris, 2006. Perkembangan dan pengembangan anak usia taman kanak-kanak, Grasindo. Jakarta. 